\title{
THE LEFT CRITIQUE OF THE EUROPEAN UNION: A VIEW FROM THE BALKAN PERIPHERY
}

\author{
Biljana VANKOVSKA, PhD \\ Faculty of Philosophy, Skopje \\ Email: biljanav@fzf.ukim.edu.mk
}

\author{
Radmila NAKARADA, PhD \\ Faculty of Political Science, Belgrade \\ Email: radmila.nakarada@fpn.bg.ac.rs
}

\begin{abstract}
The Brexit has been just one practical expression of the numerous disintegrative movements that engulfed the EU. It has offered a unique opportunity for questioning the TINA principle both in the European core and its periphery. The paper aims at elaborating the Left case against the EU, and particularly the Lexit, as it is seen generally and from the position of the left-wing movements in Europe and the Balkans. The paper focuses on a few key questions: what is the meaning of 'L/Exit'? What are the key arguments of the leftwing critique of the EU? If another (progressive) Europe is possible, where is the place of the Balkans in that new architecture? These issues have gained in urgency and importance especially since the 2019 October summit of the EU when the enlargement policy has been put on hold due to the French 'Non' to Albania and Macedonia.
\end{abstract}

Keywords: European Union, Brexit, Lexit, critique, the Balkans

\section{Context}

Assembling varied data, Steven Pinker (2012) has attempted to convince us that human beings are currently living in the "best of worlds", a world of unprecedented material wealth, declining extreme poverty and violence - wars are fewer and the number of civilian victims smaller, while major breakthroughs, advances in medicine and technological development have extended life expectancy and immensely improved the quality of life. Humans may be living in 


\section{Securitity}

the best of worlds, but they are not a happy lot (Taro 2018). ${ }^{21} \mathrm{~A}$ sense of malaise is widespread ${ }^{22}$ diverging from the assembled optimistic statistics, and this is not due to the lack of information, awareness, nor to inertia, inborn propensity to be critical but to the ongoing complex global crisis (World Bank 2019). William I. Robinson $(2014$, p. 1 ) depicts the crisis in the following manner: "Our world is burning. We face a global crisis that is unprecedented in terms of its magnitude, its global reach, the extent of ecological degradation and social deterioration, and the scale of the means of violence."

The magnitude of the crisis, it uncertain outcomes have to a large degree turned the really existing circumstances into an incomprehensible realm, simultaneously combining the best and worst of worlds, unprecedented opportunities and blind roads endangering the very existence of the human species. There is no fundamental principle - liberty, equality, brotherhood, rule of law, environmental protection that is not being affirmed and at the same time violated by the arrogance of power, greed, and indifference and turned into an uncertainty, an arbitrariness fueling both anger and apathy (Mishra 2017). The celebration of democracy and the emergence of new inaccessible locations of power, the creation of wealth and the humiliating inequalities, the increased interdependence and the decrease of solidarity, the mobility of capital and the erection of walls to prevent the mobility of unwanted human beings - migrants and refugees ${ }^{23}$, speak of the contradictory colors of the world.

The crisis of the EU is a part of global entanglements, above all the dominance of the neo-liberal (or better, ordoliberal) economic model and its consequences (Fouskas and Roy-Mukherjee, 2019). Based on the uncritical acceptance of the TINA dogma ${ }^{24}$ and in its own expansion, the

${ }^{21}$ Depression, according to the UN, has become a global epidemic, ministries for loneliness are being contemplated and suicide rates would again raise Durkhaim's curiosity. According to the article, the 2017 Report of the Jo Cox Commission on Loneliness more than 9 million people in UK, 14\% of the population, suffer from loneliness. A US survey from 2010 found that $1 / 3$ of the citizens over 45 years feel lonely. Concerning suicides Eurostat reports that "in absolute terms, Germany (10 200 deaths) and France (9 200) were the two Member States recording the most suicides in 2015, followed by Poland (5 400), the United Kingdom (4 700), Italy (4 000) and Spain (3 600)." When these absolute figures are adjusted to the size and structure of the population then the suicide rate is the highest in Lithuania and Slovenia, and the lowest in Cyprus and Greece. "Just over 56000 persons in the EU committed suicide“, 16/07/2018/ available at https://ec.europa.eu/eurostat/web/ (accessed on 25 May 2019). In a comparative perspective, the data provided by the World Health Organization for the six regions of the world (Southeast Asia, Africa, Europe, Western Pacific, Americas, Eastern Mediterranean) shows that the suicide rate in Europe was the highest - 15.4 per 100000 people per year. Global average for 2016 was 10.6. Available at https://www.who.int (accessed on 25 January 2020). 22 While the elderly in the global Center are confronting loneliness, the youth of the global Periphery are the primary victims of extreme poverty. According to the World Bank, the majority of the extremely poor are residing in Sub-Saharan Africa, and they are under the age of 18.

23 Since the end of the Cold war 15 walls have been built just in Europe, spanning from Spain to Latvia; their length is equal to six Berlin walls. Jon Stone, "The EU has built $1,000 \mathrm{~km}$ of border walls since the fall of Berlin wall", Independent, 9 November 2018, available on https://www.independent.co.uk/news/world/europe/ laccessed on 26 January 2020).

24 The acronym TINA refers to the phrase There Is No Alternative, which is de facto a slogan used by then British PM Margaret Thatcher, which meant that the market economy is the only system that works, and that debate about this is over. Throughout times, this principle has gained also political, ideological and cultural significance. As Bauman put it: "Indeed, a spectre is haunting Europe - the spectre of the absence of alternative." 
EU tends to implement the logic of "one size fits all" (Bauman 2016, p. 13). Developing an insensitivity to the growing inequalities and lacking corrective redistributive mechanisms, the EU has responded to economic crisis by delivering "socialism for bankers and austerity for the population" (Y. Varoufakis); democracy has been eroding and the extreme right arising. The value of the common good, capacity for collective action have been reduced, "moderating forces eliminated" (Streeck 2016), overwhelming the individual with the burden of finding his own answers to socially created problems (A. Giddens). The feeling of belonging to a community is replaced by rivalry, competition, consumerism, producing citizens lacking the capacity to understand their own interests.

Current cleavages in the EU run along the national and transnational axis, the democratic and authoritarian axis, and along the divisive lines between, founders and newcomers, the Core and the Periphery, the privileged minority and existentially insecure majority and amidst the pool of victims themselves and their misguided antagonisms towards the "alien" Other. Responses to these polarizations and tensions have varied from "Yellow vests", pan European movements, to pro-fascist protests and violent clashes, from trade tensions to securitization/ militarization, from initiatives to further federalize the EU to the exit of one its key members UK. The ongoing Brexit chapter (in the time of writing this article) has opened many questions, among else: Is Brexit a wrong answer/response to a right question, i.e. to some legitimate grievances? Is it a response to the suffering of the losers, or to the calculations of the beneficiaries? Is it a form of delinking (i.e. disturbing the imperial discipline of the EU in the words of Wolfgang Streeck) that is enhancing visionary thinking, showing a way to socially, ecologically sensitive, politically participative alternative? Or is it a form of preserving the present status quo by other means? Can it result in a paradigm shift that is/will enable a renegotiated reality and contribute to the broader de-legitimization of the neo-liberal logic, or is it the beginning of the end of EU? Interpretations of the motives, and consequences of Brexit vary, but we focus merely on those that come from the left political spectrum (Lexit).

The Left has been compromised as a political force by the opportunistic Third way project and it is still searching for a coherent voice, identity. The Left has indeed done badly in the recent European elections (Varoufakis 2019). Nevertheless, we consider that paying attention to the voices within this political specter that are rejecting the inevitability of the present state, i.e. sustaining the necessity and desirability of alternatives based on justice, caring for the needs of the majority, makes sense as a gesture of keeping the flame of the "better possible" alive.

\section{The Left Case against the European Union: A Sketch}

\section{a. Leave option}

Formulated during the referendum campaign on Brexit, Lexit has become a concrete left option against the EU within the Leave camp in Great Britain. It was barely audible because of the fracture between the leaders of the main political and trade-union forces on the Left and their popular and working-class base, which in its great majority rejected the EU. The Labour 
Party itself saw a split between, on the one hand, its MPs and party machine, and on the other hand a large portion of its voters.

Far from being a coherent movement, the Lexiteers have built a common agreement that the EU as a structure could not be reformed or socialised, being a neoliberal body designed to strengthen a form of capitalism which was widening inequality and reducing labour power. Leaving has been seen as the only way to break from the neoliberal structural shackles that constitute the EU. The withdrawal from the EU must include a withdrawal from all its institutions including the single market and customs union. A Norwegian-style 'soft' Brexit has been ultimately dismissed as remaining tied to the Union's wider ideological and institutional structures. Therefore Lexit was meant as an approach that calls for a clean break from the EU, whilst promoting democracy, socialism and internationalism. However, according to Owen Worth (2017) there have been internal divisions between 'internationalists' and 'left-nationalists'. The former confirming a commitment to internationalism and seeing Lexit as a vehicle where a new form of internationalism could be built - beyond the confines of 'Fortress Europe'. The 'left-nationalist' position saw internationalism and globalism as the problem and favored the return to a national struggle for socialism.

Many have been very critical towards the Lexiters. Worth (2017) argues that Lexit appeared to be rather abstract in its form. He believes that Lexit itself has been side-lined beyond repair and that the post-referendum period has not only revealed the implausibility of the Lexit position, but has also seen the left as a political force slip further and further behind. In the next couple of years many wondered if Lexit ever existed. Owen Smith (2019) goes a step further claiming that "the truth is there can be no leftwing Brexit. It is an oxymoron. It's irreconcilable with those values of freedom and equality that are at the heart of what we stand for." In his view, Lexit is dead, but democracy is alive. Having ruled Lexit impossible beforehand, Tooze (2018) argues that it is now out of bounds in the post-referendum period as well. However, he adds a comment that embraces not only Lexiters but refers to the European Left in general: "as long as it remains at the level of abstract gestures toward 'taking back control,' the impulse of resistance mirrors what it opposes. We are still not engaging with the actual mechanisms of power and production. To move beyond Hayek, what we need to revive is not simply the idea of economic sovereignty, whether on a national or transnational scale, but his true enemies: the impulse to know, the will to intervene, the freedom to choose not privately but as a political body." Many would not agree with such a pessimistic view on the European Left butwould appreciate its inspiring potential in the dialogue about the future of the EU.

Richard Tuck (2016) noticed that the majority within the British left has supported the "Remain" option because it did not want to be associated with the crowd consisting of the right, ranging from racists concerned with the recent growth of immigration to romantic global free marketeers. Yet he argued that in supporting "Remain," the left was making a profound mistake by supporting the thesis that left politics today could only be advanced by concerted action within the EU. According to Tuck that is a fantasy because the EU represents a constitutional order tailor-made for the interests of global capitalism and managerial politics: "As the juris- 


\section{Security}

prudence of the EU has developed, it has consistently undermined standard left policies such as state aid to industries and nationalization. Constitutional structures that are largely outside the reach of citizens have, in the modern world, tended almost invariably to block the kind of radical policies that the left has traditionally believed in. The central fact about the EU, which the British governing class has never really got its head around, is that it creates a written constitution and ancillary juridical structures that are extremely hard to alter." The EU cannot be reformed in a progressive direction, with a more democratic mode of functioning, because its very architecture is designed not to be reformable (Kouvelakis 2016).

\section{b. Remain option}

In addition to the so-called Plan B or Left Exit, the British left witnessed another left option within the Remain block. Yanis Varoufakis, the former Syriza finance minister, played a significant role in promoting the pan-European version of TINA, which may be summarized as There is No Alternative to the European Union. The reformist alliance known as Democracy in Europe Movement 2025 (DiEM25) was formed more than half a year before the British referendum. Its slogan read "The EU will either be democratised or it will disintegrate!" In the DiEM25 Manifesto the idea is explicated further: "If we fail to democratise Europe within, at most, a decade [... ], then the EU will crumble under its hubris, it will splinter." In its current form the EU has alienated Europeans and is stirring up 'a dangerous anti-European backlash'. The notion of possible disintegration of the EU is obviously something that cannot be further ignored (Patomäki 2017). Varoufakis basically agree with the Lexiteers: "the EU was intentionally constructed as a democracy-free zone that would keep the people out of decision-making and defer to a cartel of big business and international finance. Saying that the European Union suffers from a democratic deficit is like saying an astronaut on the moon suffers from an oxygen deficit." Yet DiEM25 suggests a creation of a pan-European movement of civil and governmental disobedience that will produce a surge of democratic opposition to how European Union elites do business at the local, national, and international levels (Varoufakis 2016).

The 2019 European elections seem to prove Kouvelakis' argument (2016): "If the Left that says it is hostile to neoliberalism continues to repeat the litany of slogans about 'social Europe' and the 'reform of European institutions,' it will not simply reduce itself to impotence, but will be entirely swept away." The Left has remained split between multiple projects, and none of them have a clear idea how to transform the EU - or how to persuade the voters to give them a chance (Balhorn 2019).

\section{The Left Critique of EU}

Brexit was surely not the first time for the European Left to question the EU integration from the left position. ${ }^{25}$ Seen from a historical point of view, some authors argue that the EU

25 The idea of Grexit during the 2015 crisis in Greece was only an idea, never backed by a coherent plan for implementation, and it referred only to Greece's exit from the Eurozone but not abandoning of the ET as such. In addition to 


\section{Security}

is a modern reflection of an old tendency in the entire European history, i.e. empire-building (Engel-Di Mauro 2006; Chandler 2006). The frequent equalization of Europe with civilization only confirms the thesis about the self-potrait which the EU offers representing itself as a universalist vision entangled in the centuries-long history of the continent. Unlike the old empires that had been spreading through military power, today's soft imperialism is embeded on economic might and cultural/normative values. In addition, some authors suport the theory that the main motivation of the member-states is also very different from the historical examples: the economic power of today steams from the interests of the corporate capital that needs vast and open markets, and possibilities to increase profit-making (Hofbauer 2004; Schmidt 1999).

In practical and theoretical terms many misunderstandings are due to the identification of the EU with Europe as such. Actually, this kind of dicourse is promoted the most through the creation of a specific Euro-speak and Euro-symbolism, mostly by the EU official representatives (Diez 1999). There have been numerous ideas and visions as well as practical attempts for European integration/unification; even today the EU is not an exclusive European international organization that portrays so-called European values. One should also keep in mind that the states/ societies that are not formally parts of the EU are not less European than the member-states. Europa is a much wider notion than the EU. What differentiates the EU from the other European (and non-European) associations lies in the fact that it is the most powerful subject that unites political power, authority and governing achitecture. The EU has from the outset been an object of criticism because of its dominant elitist and hierarchical elements that overshadows the horizontal networking and the uniting of civil societies, citizens and other societal actors. Generally, the EU suffers from a lack of democratic essence, citizens' participation, the weak European identity, etc. The Union functions as a set of constraints on the internal politics of its member states exactly as did the bourgeois constitutions of the mid-nineteenth century (Tuck 2016). At the same time, the EU is a global phenomenon that incorporates in itself elements of imperialism and neocolonialism (Böröcz and Kovács, 2001; Dabashi 2019).

The proponents of the EU, usually and widely credit it with bringing about both peace and prosperity on the continent (or at least, a part of it). However, the left critics disagree and claim that the EU's record can sustain neither claim. They detect that the origins of European integration are deeply intertwined with colonialism and the Cold War. According to Joe Guinan and Thomas Hanna (2017), Monnet's vision effectively involved 'nothing less than integrating Europe around the nucleus of what would have become a military-industrial complex' topped off by a dangerously unaccountable executive with ill-defined powers. Susan Watkins (2016) points out that the idea that European integration delivered peace might raise eyebrows among, say, Algerians or Irish republicans, given the continuing record of neo-colonial violence, while EU foreign policy and the European armaments trade have played their part in creating a 'widening arc of devastation that now surrounds it', from Ukraine and the Balkans to Iraq, Libya, Syria,

Greece, there is a long list of member-states whose leadership constantly questions the EU principles and the status quo - because of different reasons and from various (non-left) ideological positions. In this paper, however, we explore basically a radical left critique of the EU. 


\section{Securitity}

and Yemen. On the economy, decisive pressure toward market integration 'came from a powerful neo-liberal culture aimed at the removal of national barriers to trade' (Sassoon 2014). Long ago Tom Nairn (1972) wondered: "We know, indeed, that the common market is intended to strengthen the sinews and the world-position of European capitalism and its various ruling classes. What we do not know... is whether, or in what ways, it may also strengthen the position and enlarge the real possibilities of the European working classes." Decades later the answer is self-evident.

Guinan and Hanna (2017) argue quite convincingly that from its inception, the EU has been a top-down project driven by political and administrative elites. They refer to the definition of the EU as a political system constructed by national political leaders as a protected sphere in which policy-making can evade the constraints imposed by representative democracy (Mair 2013). Acordingly, to complain about the EU's 'democratic deficit' is to have fundamentally misunderstood its purpose. The main thrust of European economic policy has been to extend and deepen the market through liberalisation, privatisation, and flexiblisation, subordinating employment and social protection to goals of low inflation, debt reduction, and increased competitiveness. Eventually, European socialists ended up surrendering the tools they possessed at home. Donald Sassoon (2014) pointed out that "in the name of the international requirements of modern capitalism", governments were required to accept the abandonment of internal - that is national - regulation. The 'end of history' delusions were constitutionalised in the EU treaties. The results could be seen in the growing income inequality, erosion of workers' rights, etc. Meanwhile, any attempt to create a different kind of economy from inside the EU has been forestalled by European law. This has happened across a range of economic areas: trade, financial regulation, state aid, government purchasing, public service delivery - many of the things the Left might conceivably wish to do would likely fall foul of competition policy or single market regulation. Martin Höpner (2008) concludes: "Let us stop romanticising European economic integration, seeing it as a democratic, social project. It is neither democratic nor social."

As evidenced by many scholars, from being broadly sceptical of the European project in the 1960 s and 1970s, the European left has transformed to being broadly supportive. Hugo Radice $(2015,119)$ argues: "What is needed now is a far more arduous 'long march' into and across the European Union, constructing a popular movement against neoliberalism based on common concerns about equality, citizenship, human rights and the environment, and engaging unions and social movements as well as the groundswell of broader opposition since 2003 to European complicity in the renewed imperial adventures of the US regime". This developments has had collateral impact on the very discourse on Europe/EU. Some argue that the progressive discourse on Europe is full of taboos and myths, and entering these debates requires caution: "It's a challenge to clearly articulate the social consequences of European integration and, in so doing, come into conflict with the myth of 'Social Europe'. It does not take much to be inadvertently painted as a Eurosceptic." (Höpner 2018)

If anything good has come out of the political atmosphere surrounding Brexit and its aftermath, it is the fora it provided for many others to re-consider their positions regarding the EU. Ever since the deepening of the 2008 financial and economic crisis in the West, and particularly 
in the Brexit context, questioning the EU de facto became a 'matter of emergency' in the face of the economic and financial crisis, within the general context of "the divorce between capitalism and democracy" (Puhovski 2012; Dolenec and Žitko 2016; ). In other words, everything that had been covered up and hid for years all at sudden became a Hamletian dilemma that was to be answered by the citizens of only one country - Greece.

The left case/critique of the EU deserves greater attention because of two key reasons: first, this approach and discourse have been intentionally overshadowed (in political and academic terms) because the Left was in retreat and in disarray especially at the time when the EU was a shining example of prosperity and peace, and second, with the crisis of capitalism deepening further one may expect this debate to gain in significance. One of the premises of this paper is that the EU (or more precisely, all historical forms in which the EU had been manifesting itself, starting from the ECSC in 50 -es up to date) could be seen as a child of the honeymoon between capitalism and democracy. Nowadays, eminent scholars debate the end of capitalism as something that is ongoing, turning the present into a period of interregnum between two systems. It is a period, as Antonio Gramsci showed, in which the most unpredictable events can occur. So the end of capitalism, Streeck (2016) argues, will materialize as a slow fading away of our social order into a successor regime whose superiority, or indeed its nature, we cannot predict. His answer to the question how exactly this fading away will occur reads: capitalism will end from an overdose of itself. Inevitably, another question follows this premise: Is the European Union possible without capitalism? And will it end from an overdose of "More Europe"?

Costas Lapavitsas' book (2018) The Left Case against the EU is combining the left voices from the core and the periphery contesting the EU, partly because of the author's background and experience, and mostly because the working class in two very different EU member-states have sought for the answer of the same question: is leftist/socialist EU/Europe possible under the current institutional, economic and political constellations? This is one of the boldest books in terms of its clear and unequivocal conclusion: anyone on the Left has to be foursquare against the EU. Lapavitsas' analysis traces the evolution of the EU since the Maastricht Treaty as well as the German conditional hegemony. The 'Four Freedoms of the EU', which were already stipulated in the Treaty of Rome, were reasserted by the Maastricht Treaty in a way that would lead to their interpretation as individual rights. Thus, the free movement of goods, the free movement of capital, the free establishment and provision of services, and the free movement of persons all became tools used by the interests of capital against collective interests and policies. He argues that it is striking how little attention the Left pays to this foundational aspect of the EU: it is not a neutral set of governing bodies, institutions and practices, but it has evolved to serve the interests of capital and above all a particular dominant class in the form of German industrial export capital. He concludes that the EU has not generated convergence within Europe, instead creating a core - France, the Netherlands, Austria, Italy (with one foot outside the core), and Germany - with a Southern periphery (Spain, Portugal, and Greece) and a Central European periphery (Poland, the Czech Republic, Hungary, Slovakia, and Slovenia). The economic dynamic of the EU and the EMU creates divergence, which is a necessary outcome of EU membership. The 
failure of the SYRIZA in Greece is used as a concrete proof that reform of the EU is impossible, not only due to the internal weakness of the Left alliances, but even more because of the very nature of the institution of the EU itself. Lapavitsas argues that the EU is a 'transnational juggernaut'; it is the key mechanism through which the depoliticization of national politics occurs in member states and the central mechanism for the maintenance of an economic system that benefits national capitalist classes and specifically German export capital. It is incompatible with socialism in every way. It is a way that national elites remove decision making from contestation at the national level. Starting from the point that the EU is a non-neutral political institution and is not identical to internationalism, he counters the arguments on the part of the European Left that the EU should be defended in the name of this internationalism while its neoliberal policies are criticised. Lapavitsas is particularly concerned to dispel the 'remain and reform' argument, concluding that "to hope the outlook of the EMU and the EU could be altered through the simultaneous election of left-wing governments in core countries, drawing upon common anti-neoliberal politics and supported by grass-roots workers' movements, is to add fantasy to misunderstanding"' (ibid., p. 7). Relatedly, it is important for the Left consistently to make the case that the EU is not a truly international organisation for a number of reasons, while distinguishing the contingent reasons for this-among others that there are different ideas of Europe not only the EU project, that the EU's supposed internationalism comes at the cost of a host of exclusions and a brutal southern border, and that concretly there are few if any Greeks who would have felt any international solidarity from the EU since 2010. The EU as an institution functions to privilege not just the interests of capital over labour, but the interests of specific national capitals (German) over other national capitals.

\section{The Meaning of Lexit in the Balkan Context}

The end of the Cold war, among other illusions, gave birth to the idea of unification of the Balkans on the ground of common/shared (Western) values and joint integration in NATO and the EU. The bloody demise of Yugoslavia postponed this dream for some time. Yet it is worth mentioning that its disintegration begun with the (Slovenian) slogan "Europa Zdaj" (Europe Now). As economically the most developed YU republic, is was the first one to put priority on liberal transformation and economic interest at the expense of the common state (which had already been in turmoil due to the deep economic and societal crisis). The rest of Yugoslavia had to go through far more troublesome experiences before gaining independence and statehood. Yet the elites of all the newly established states, once the wars/conflicts had ended, quite early stated that NATO and the EU are their primary goals, along with neoliberalism in economic and political terms. The EU elites coined the meaningless term of Western Balkans for the troublesome (and rather hopeless) state entities (ex-Yugoslavia minus Slovenia and then Croatia, plus Albania). Bulgaria and Greece (and in wider terms, Romania if included in the Balkans) represent the troublesome EU periphery. In this context, however, one should single out Greece when it comes to the left traditions and overt criticism of the EU core countries. SYRIZA victory would have normally provoked enthusiasm and motivation with other left forces in the region but it was 
met with silence with few exceptions in Serbia and Croatia on the political fringe. In reference to Brexit, the reactions were either concerned with its implications on the further enlargement of the EU, or solidifying arguments of those (mostly on the right spectrum) who were Eurosceptic.

The countries that were born out of the socialist Yugoslavia swiftly embraced TINA principle, while the burden of the 'original $\sin ^{\prime}$ (of Communism) prevented the rebirth of any far leftist ideology or organization. Having in mind that the nation-building and state-building processes have been directed from the external power centers (Chandler 2006), the priority in each of these countries were normalization and stabilization. Stabilitocracy has become the 'only game in the town'. As Srdja Pavlovic (2017) rightly stresses, "the core value of stabilitocracy is a conviction that protecting and promoting western interests is paramount... Regimes which understand that core conviction and are willing to protect and sustain western geo-political, security, military, economic, or energy related interests in a given country are usually spared the wrath of the great powers such as the United States, the UK, or the European Union. Local autocrats, therefore, can do whatever suits their needs in their private domains. Any criticism directed towards them is usually dismissed as either sour grapes from a political loser or an attempt by retrograde undemocratic political forces to gain the upper hand."

The former communists have been the most effective turncoats and fervent advocates of economic liberalism. The former socialist block has turned into a world where parties of the centre left and right tended to follow similar economic policies, all prescribed by the West. The only difference may be seen in the gradual swich from Washington consensus towards the Berlin-based ordoliberalism, a tendency that corresponded with the change of geopolitical interests of the US and EU. There is practically no anti-capitalist critique at all, and least when it comes to the EU - it has become a 'sacred cow of democracy and progress'. In return, the EU state-builders (ambassadors, special representatives and other officials) have imposed a differential treatment towards the societal and political subjects in these states. This can be illustrated through exposing the different treatment of the social movements, plenums and 'revolutions' in Bosnia and Herzegovina and Macedonia. The EU remained suspiciously silent and quite worried with the 2014 developments in B\&H where the plenums mobilized the working class and the poor citizens united around the demands for social justice and grass root civic engagements against top-bottom governance of the corrupted elites (Puljek-Shank, 2019). In Macedonia, however, the support for the regime change through so-called Colorful revolution (2014/16) was hardly hid.

Peter Ramsay (2018) rightly points out that EU membership undermines the left in the member-states, but almost the same arguments could be used for elaboration how bids for EU membership eradicate any possibility for the left in the periphery to become a viable political force. The EU is a political form through which the governments collaborate with each other by constitutionalising various restrictions on economic policy, and by law-making in intergovernmental forums bypassing their own citizenry. Ramsay stresses that this intergovernmental process means that European governments are more accountable to each other than they are to their domestic legislatures. The only difference with the non-EU states (periphery) lies in the fact that national governments do not have power to collaborate but to obey, and they are more 


\section{Secuurity}

accountable to Brussels (and Berlin) rather than to the citizens that elect them in office. The Bulgarian analyst Ivan Krastev put it rightly long ago (before his country of origin had become a member of NATO and EU) "our government make love with the citizens, but they are loyal to the international community." The EU has systematically undermined the solidarity within its own borders, pursuing policies that have created a northern core and a southern periphery with disastrous consequences for the states in the periphery (Ramsay 2018). It concerns not only austerity, liberalization and privatization policies, but also the migration policy. The citizens have always been seen as untrustworthy, and in time of crisis the national leaders complain in Brussels that "their people are nationalists". The politics of conditionality and (promised) enlargement have been more about discipline and state building from the top rather than about political pluralism and participation.

From the point of view of the potential EU member-states, one finds a range of reasons for their enthusiastic wish to join the Union. Among the others, Catherine Samary (2011) points out the following as the driving force for the former Eastern European states (and they are quite relevant for the Balkan region as well): the image of a "European social model" is explicitly used at an ideological level by the European governing institutions to force people to vote in favor of the EU; and the popularity, especially among young people, of the alleged withering away of frontiers - a hope later dashed by anti-immigrant witch hunts, racism and new walls of poverty. In sum, it seems that the peripheral countries (in 2004 as well as in 2019) preserve the belief that joining the EU would make them less peripheral.

It took quite some time and courage for the new far leftist movements and parties to appear in the post-conflict Balkans. Many of them still take rudimentary forms of organization, and suffer from the infantile disorder syndrome (to paraphrase Lenin), internal divisions, dogmatism and sectarianism. These parties usually have no access to mainstream media and are marginalized as well as self-marginalized in the political life. At glance, the generations who grew up under the transition take the initiative to formulate left ideology and vision. They are not only inexperienced but also distrustful towards anyone who is older (seen as a 'baggage' or 'old guard' rather than an asset in their political work). Functioning barely on membership fees and small donations from left-oriented foundations they are ill-connected to the similar organizations in Europe, and even from the region. Just a handful of these political parties have clearly articulated their position vis-à-vis the EU integration. For instance, the first ever far left political party in Macedonia, Levica has shown enough courage to spell out anti-NATO stand (as the only one on the political scene), but the wording with regard to the EU is rather ambiguous and hard to decipher (there is a reference vis-à-vis the potential benefit of the membership). The lack of critical thinking has a general scope, but there is even less left-wing deliberation on the developments in the EU. There are occasional gatherings and exchanges among the minor political parties from the region (Macedonia, Serbia, Turkey, Greece) but none of these parties have a say in the national political arena. The left-wing social movements are even rarer phenomenon.

Kouvelakis (2016) rightly refers to fear mongering and propaganda as a response to any radical critique of the EU: "On each occasion those who defended the EU brought along less and 
less positive discourse and essentially employed arguments founded on intimidation and fear, putting into the spotlight all the ills that would come down on the United Kingdom in the British voted the wrong way." The same applies to the non-member states in the EU periphery since the elites, and even more the citizens are disciplined the identically by pointing out that if they do not aspire to join the Union they will cease to exist or will get involved into a renewed wave of ethnic conflicts. The geopolitical situation and the revival of the Cold War 2.0 does not lessen the state of affairs because any anti-EU stance is immediately categorized as anti-Western (i.e. anti-civilizational) and even pro-Russian. The EU has become a dominant secular religion and an ultimate goal of state/people existence. That the EU 'values' and interests outshine the basic national interests or even human rights can be seen in the Macedonian case: the imposed name change but also the change of the constitution at the expense of the rule of law and in clear violation of human rights have been legitimized by 'higher interests' - i.e. membership to NATO and the EU. The left did not object too strongly fearing that it would be labelled as nationalistic. The impoverished and disenchanted citizens did not protest in hope that the country's European integration would bring better life.

\section{Tentative Conclusions}

The European Left (as well as the global left) have been in disarray for a long time now. The left debate over Brexit and the future of the EU reminds of the old dilemma whether it is possibile to introduce socialism in one country, or in this case: is it impossible to dismantle EU institutional and power structure in one of its former members and simultaneously to build a socialist system instead. Boris Kagarlitsky (2017, p. 110) rightly argues that the key problem is to be found in the Left itself. Instead of ideological capitulation and acceptance of neoliberalism as something objectively inevitable, the left has missed an opportunity to replace the narrative of 'progressive' cultural values allegedly related to the EU (the new capitalist hegemony) with class struggle. According to him, "the Brexit vote was not only a rebellion against the neoliberal European project but also no less a popular uprising against Britain's own ruling elites, including both intellectual and political classes, business and media."

The significance of any left case contesting the EU is not marginal or totally defeated as it may seem at first sight. Lexit may be temporarily dead or irrelevant, but it nevertheless gives hope that capitalism and its children (such as EU and NATO) are not untouchable to the left theoretical and practical critique no matter how scarce and marginalized it is. When it comes to the Balkan periphery, spelling out the left arguments against the idolatry and worship of the EU equals a revolutionary act per se, bearing in mind that these societies have lost the political struggle and popular sovereigny in their nation states. In this context, L/Exit has a meaning of intellectual and political emancipation (exit from the EU matrix) and reconsidering the region, the Continent and the world through an internationalist prism that does not call for blind obedience to prescribed socio-economic and political therapy from Berlin or Brussels.

The popular Left faces huge challenges - to find the fine tune for both popular sovereignty and internationalism. The less developed Balkan states face a two-fold challenge: how to gen- 
uinely democratize their countries, while struggling against both national and international capitalist classes. The left is supposed to start the struggle with expanding popular sovereignty, in order to give the people a greater say over the decisions the influence their lives. The internationalist ruling class (transnational class, W. I. Robinson) has demonstrated how can obtain its class aims by moving on to the 'European' terrain, simultaneously forcing (or perhaps simply allowing) the left to retreat back to the lost ground of nationalism and 'national sovereignty'. In order to avoid self-marginalization and provide for a rise of right-wing populism, the struggle should start with concentrated hegemonic cultural and intellectual efforts whose aim is to change the general public climate, dominant media discourses, and re-introduce progressive ideas into wider society. undermining the (neo)liberal hegemony.The current state of affairs calls for deconstruction of the myths and taboos about the EU as a general solutions for all problems and identification that all the everyday problems of the citizens are more or less related to the neoliberal European medicines. The synergy between the left in the developed parts of Europe and its periphery is of crucial importance and priority in the coming period. The left in the periphery could be empowered by the counterparts in the core countries, and vice versa.

\section{References}

1. Balhorn, Loren (2019), "The European Left in Disarray", Jacobin, 24 May, available at

2. https://www.jacobinmag.com/2019/05/european-union-elections-left-wing-parties (accessed on 20 March 2020)

3. Bauman, Zygmunt, Donskis, Leonidas (2016), Liquid Evil, London: Polity Press.

4. Böröcz, Jozsef, Kovács, Melinda (eds.) (2001), Empire's New Clothes: Unveiling EU Enlargement, Telford: Central Europe Review Ltd..

5. Chandler, David (2006), Empire in Denial: The Politics of State-Building, London: Pluto Press.

6. Dabashi, Hamid (2019), Europe and Its Shadows: Coloniality After Empire, London: Pluto Press.

7. Diez Thomas (1999), "Speaking 'Europe': The Politics of Integration Discourse", Journal of European Public Policy, vol. 6. no. 4.

8. Dolenec Daniela and Mislav Žitko (2016), "The Unhappy Marriage of Capitalism and Democracy at the Root of Europe's Crisis", Green European Journal, 1 July, available at https://www.greeneuropeanjournal.eu/the-unhappy-marriage-of-capitalism-and-democracy-at-the-root-of-europes-crisis/ (accessed on 20 January 2020)

9. Engel-Di Mauro, Salvatore (ed.) (2006), The European's Burden: Global Imperialism in EU Expansion, Peter Lang Publishing.

10. Fouskas K. Vassilis and Shampa Roy-Mukherjee (2019), "Neo-liberalism and Ordoliberalism - One or Two Critiques? An Introduction", Critical Sociology, vol. 45, issue 7-8.

11. Gillingham, John (2016), The EU: An Obituary, London: Verso.

12. Gjorgjioska, Adela (2016), "Social upheaval in times of neoliberalism: The deep roots of Macedonia's protest wave", LeftEast, 22 April, available at http://www.criticatac.ro/ 


\section{Security}

lefteast/social-upheaval-in-times-of-neoliberalism-the-deep-roots-of-macedonias-protest-wave/

13. Guinan, Joe, Hanna, M. Thomas (2017),'Forbidden Fruit: The Neglected Political Economy of Lexit", IPPR Review, vol. 24(1).

14. Heartfield, James (2013), European Union and the End of Politics, Zero Books.

15. Höpner, Martin (2018), "Social Europe Is a Myth", Social Europe, 5 November, available at https://www.socialeurope.eu/social-europe-is-a-myth

16. Horvat, Srecko, Stiks, Igor (2014), "The new Balkan revolts: from protests to plenums, and beyond", Open Democracy, 12 March, available at https://www.opendemocracy.net/ en/can-europe-make-it/new-balkan-revolts-from-protests-to-plenums-and-beyond/

17. Kagarlitsky Boris (2017), "Brexit and the Future of the Left", Globalizations, 14 (1).

18. Kouvelakis, Stathis (2016), "The EU Can't Be Reformed", Verso, 26 June, available at

19. https://www.versobooks.com/blogs/2726-the-eu-can-t-be-reformed

20. Lapavitsas, Costas (2018), The Left Case against the EU, London: Polity.

21. Mair, Peter (2013), Ruling the Void: The Hollowing of Western Democracy, Verso.

22. Mishra, Pankaj (2017), Age of Anger, Allen Lane.

23. Nairn Tom (1972), "The Left Against Europe“" New Left Review, September-October, no. 75.

24. Patomäki, Heikki (2017), "Will the EU Disintegrate? What Does the Likely Possibility of Disintegration Tell About the Future of the World?", Globalizations, Vol. 14, No. 1

25. Pavlovic, Srdja (2017), "West is best: How 'stabilitocracy' undermines democracy building in the Balkans", LSE Blog, May available at https://blogs.lse.ac.uk/europp blog/2017/05/05/west-is-best-how-stabilitocracy-undermines- democracy-building-in -the-balkans/

26. Pinker, Steven (2018), Enlightenment Now, Penguin Random House.

27. Puhovski, Žarko (2012), "Demokracija i kapitalizam", Peščanik, 24 December, available at https://pescanik.net/demokracija-i-kapitalizam/ (accessed on 20 January 2020)

28. Puljek-Shank, Randall (2019) "Activism in Bosnia-Herzegovina: Struggles against Dual Hegemony and the Emergence of "Local First"', East European Politics and Societies and Cultures, Vol. 33(1).

29. Radice Hugo, Global Capitalism: Selected Essays (2015), NY: Routledge.

30. Robinson, I. William (2014), Global Capitalism and the Crisis of Humanity, Cambridge University Press.

31. Samary, Catherine (2011), "Crisis in the EU: From the Periphery to the Center", Solidarity, November/December, available at https://solidarity-us.org/atc/155/p3436/

32. Sassoon, Donald (2014), One Hundred Years of Socialism: The West European Left in the Twentieth Century, I.B. Tauris.

33. Schmidt, Vivien (1999), "Convergent Pressures, Divergent Responses: France, Great Britain, and Germany between Globalization and Europeanization" in: David A. Smith et al (eds.), States and Sovereignty in the Global Economy, London: Routledge.

34. Streeck, Wolfgang (2019), "Democracy a challenge to the European project, The EU is a doomed empire", Le Monde Diplomatique, May, available at https://mondediplo. com/2019/05/06eu.

35. Streeck, Wolfgang (2016), How Will Capitalism End: Essays on Failing System, Verso. 
36. Taro, John (2018), "How the World's First Loneliness Minister Will Tackle 'the Sad Reality of Modern Life"', Time, Apr. 25, available at https://time.com/5248016/tracy-crouch-uk-loneliness-minister/ (accessed on 25 May 2019)

37. Tuck, Richard (2016), "The Left Case for Brexit", Dissent, 6 June, available at https:// www.dissentmagazine.org/online_articles/left-case-brexit

38. Varoufakis, Yanis (2016), And the Weak Suffer What They Must?, Bold Type Books.

39. Varoufakis, Yanis (2016), "Europe's Left After Brexit", September, available at https:// diem25.org/europes-left-after-brexit/

40. World Bank (2019), Poverty Overview, April 3, available at https://www.worldbank.org/ en/topic/poverty/overview/ (accessed on 25 January 2020).

41. Worth, Owen (2017), "Whither Lexit?", Capital \& Class 41(2). 